\title{
Nonfinancial Firms as Large Shareholder Use Dividend Policy for Management Monitoring in Brazil
}

\author{
Vicente Lima Crisóstomo \\ Universidade Federal do Ceará, Brasil \\ vicentelc@gmail.com \\ José Wellington Brandão \\ Universidade Federal do Ceará, Brasil \\ brandao_93@hotmail.com
}

\begin{abstract}
The paper analyzes whether nonfinancial firms as large blockholders of the Brazilian firm shape dividend policy. Under the Agency Theoretical framework a set of good corporate governance practices is suggested as able to control management activity and prevent managers from incurring in moral hazard problems and the emergence of excessive management power as predicted by the Managerial Power Hypothesis. In this context, the Management Monitoring Hypothesis proposes that dividend policy may be used as a management control mechanism given that dividend distribution affects the free cash flow available for managers. Dividend models were estimated by the Generalized Method of Moments (GMM) for an unbalanced panel data, composed of 1.890 firm-year observations of 234 companies listed on the BM\&FBovespa, in the period 1996-2012. The results indicate that nonfinancial firms as large shareholders increase dividend payout which leads to the reduction of free cash flow. This result is in accordance with the monitoring hypothesis which predicts the reduction of free cash flow available for managers through dividend policy.
\end{abstract}

KEY-WORDS: Dividend policy. Management monitoring hypothesis.

Ownership structure. Nonfinancial firm as dominant blockholder. Brazil. 


\section{Firmas não financeiras como grande acionista usam política de dividendos para monitoramento da gestão no Brasil}

\section{RESUMO}

O artigo analisa se empresas não financeiras como grandes acionistas da empresa brasileira ajustam a política de dividendos. Sob o marco teórico da Agência, um conjunto de boas práticas de governança corporativa é sugerido como capaz de controlar a atividade de executivos e evitar que estes incorram em problemas de risco moral e surja o problema de excesso de poder da gestão como previsto pela Hipótese do Poder Gerencial. Neste contexto, a Hipótese de Monitoramento da Gestão propõe que a política de dividendos possa ser usada como mecanismo de controle dos executivos, uma vez que a distribuição de dividendos afeta o fluxo de caixa livre disponível. Modelos de dividendos foram estimados pelo Método de Momentos Generalizados (GMM) para um painel de dados não balanceado, constituído por 1.890 observações anuais de 234 empresas listadas na BM\&FBovespa no período 1996-2012. Os resultados indicam que as empresas não financeiras como grandes acionistas incrementam o pagamento de dividendos, o que leva à redução do fluxo de caixa livre. Este resultado está de acordo com a hipótese de monitoramento que prevê a redução do fluxo de caixa livre disponível para os executivos através da política de dividendos.

PALAVRAS-ChAVE: Política de dividendos. Hipótese de monitoramento da gestão. Estrutura de propriedade. Empresa não financeira como grande acionista. Brasil. 
Relevant works highlighted the importance of dividend policy under distinct theoretical frameworks and gave rise to a prominent body of research (Black, 1976; Lintner, 1956; Miller \& Modigliani, 1961). Recent literature pointed out that it still remains an open topic of study with important questions that deserve attention about dividend policy determinants (Gopalan, Nanda, \& Seru, 2014; L. E. Harris, Hartzmark, \& Solomon, 2015; Javakhadze, Ferris, \& Sen, 2014; Mori \& Ikeda, 2015; Renneboog \& Trojanowski, 2007).

Financial decisions are crucial for any company given the importance they have on firm value, and on firm performance. Among the main firm financial decisions are the ones related to investment and capital structure policies, as well as dividend policy. Every company looks for the perfect combination of these policies in order to adequately maximize firm growth opportunities and increase firm value in the mid and long run. A large amount of research has been undertaken focusing on the relation between this set of firm policies and market imperfections that are able to moderate them (Barclay \& Smith, 2005; M. Harris \& Raviv, 1991; Stein, 2003). This body of research has found that indeed financial decisions matter for firms, contrary to the predicted irrelevance of investment funding and dividend policy over firm value by the perfect market framework proposal of Modigliani and Miller, 1958). Dividend is central in this context since it is related to the cash flow available for management use. The reduction in dividend payout favors the increase in cash flow directed to firm investment funding, thus reducing the need for external funds (M. Harris \& Raviv, 1991; Myers, 1977, 1984; Pindado \& De la Torre, 2006; Stein, 2003).

The institutional and legal environment has been seen as a factor that matters for dividend policy given that the legal rules in each country may shape shareholder protection and behavior (Javakhadze et al., 2014; La Porta, Lópezde-Silanes, Shleifer, \& Vishny, 2000). Under the Agency Theory framework, agency conflicts seem to have a role on dividend policy. For instance, a number of shareholders consider dividend policy relevant for different reasons. Dividend is an important investment return for shareholders although firm value creation is even more important. Dividend policy is also related to the availability of internal funds for investment funding which is an important source of financing according to the Pecking order theory. Dividend payout will 
also determine the free cash flow available for managers, something that is dangerous for firms without good investment opportunities. In this vein, corporate governance and ownership structure emerge as important factors that could influence firm dividend policy given the interests of different groups of shareholders (Florackis, Kanas, \& Kostakis, 2015; Gopalan et al., 2014; Harada \& Nguyen, 2011; Jensen, 1986; Khan, 2006; La Porta et al., 2000; Lee, Liu, Roll, \& Subrahmanyam, 2006; Mori \& Ikeda, 2015).

In the context of the agency conflicts between shareholders and managers there is a set of good corporate governance practices that are suggested as able to control management activity and prevent managers from incurring in moral harzard problems and the emergence of excessive management power as predicted by the Managerial Power Hypothesis (Guthrie, Sokolowsky, \& Wan, 2012; Shleifer \& Vishny, 1997). In fact, some agency models that take into account corporate governance practices and the role of shareholders have been proposed for the explanation of the relationship between ownership structure and dividend policy (Florackis et al., 2015; Gopalan et al., 2014; Harada \& Nguyen, 2011; Khan, 2006; Mori \& Ikeda, 2015).

The relevance of research about dividend policy in emerging markets has increased with the growing importance of such economies and also for the fact that the institutional and legal environments have specific nuances that may interfere in shaping dividend policy (Javakhadze et al., 2014; La Porta et al., 2000). In this context, Brazilian market has a set of specific characteritics that makes it an important economy that requires attention: the greatest economy in Latin America, high firm ownership concentration, low protection of minority shareholders, minimum mandatory dividend policy of $25 \%$ of net income in Brazil (Law no. 11.638/2007), high private benefits of control that favor large controlling shareholders (Brandão \& Crisóstomo, 2015; Dyck \& Zingales, 2004; Holanda \& Coelho, 2014; Procianoy \& Verdi, 2009). Besides, some macroeconomic events also make dividend policy an interesting topic to be analyzed in Brazil: the drop in inflation, from 1994, and the process of poststabilization, the growth of stock market capitalization, and the importance given to the adoption by firms of good corporate governance practices (Moreiras, Tambosi Filho, \& Garcia, 2012; Procianoy \& Verdi, 2009). Most of the studies about dividend policy in Brazil started after the economic 
stabilization in the 1990 's. Studies focusing on agency conflicts and dividend policy are still scarce (Martins \& Famá, 2012).

Given that dividend distribution is related to cash flow available for management use, debt or dividend policy may be used as instruments to avoid excess free cash flow in hands of managers (Jensen, 1986). This work aims to assess whether dividend policy of Brazilian firm is shaped by one relevant aspect of ownership structure, the presence of nonfinancial firms as the dominant controlling stockholder. The possible positive effect of high ownership concentration in hands of nonfinancial firms on dividend payout is studied. Such positive effect could signal that these controlling shareholders may be using dividend policy as a management control mechanism.

For a representative panel data composed of 1.890 firm-year observations relative to 234 companies, in the period 1996-2012, the results indicate that indeed there is a positive effect of nonfinancial firms as large controlling shareholders on dividend payout of the Brazilian firm, which is in line with the management monitoring hypothesis.

This document has the following structure. In the next section, theoretical framework addressing the issues involving dividend policy, ownership structure, and the agency conflicts that drive the monitoring hypothesis are concatenated. Then, data source, the procedures for the data collection, and the methods used for data analysis are presented. At continuation, results are exhibited and commented. Finally, concluding remarks are offered.

\section{DIVIDEND POLICY AND HYPOTHESIS}

\subsection{DIVIDEND POLICY AND AGENCY CONFLICTS}

By showing that dividend policy is not irrelevant for firms Lintner (1956) provided an important contribution to dividend policy research. According to Lintner, firm managers avoid reducing dividend distribution and adjust it periodically in a way to avoid dividend volatility higher than firm earnings per share. Since Lintner's contribution, a body of research on dividend policy has been built. This initial research on dividend policy led to the important proposal that firm income seems to be a central factor on dividend payout which has 
almost become a consensus with evidence documented (Fama \& Babiak, 1968; Lintner, 1956; Short, Zhang, \& Keasey, 2002; Waud, 1966). Besides the reality that profitability seems to be an important determinant of dividend payout, the question of which firm attributes moderate firm dividend policy has been the focus of important research and remains an open avenue for investigation (Black, 1976; Bøhren, Josefsen, \& Steen, 2012; DeAngelo, DeAngelo, \& Skinner, 2008; Gordon, 1959; Gutiérrez Urtiaga \& Sáez Lacave, 2014; Lintner, 1956; Miller \& Modigliani, 1961).

Among the possible determinants for dividend policy, dividend tax treatment emerged as an important one in different markets according to distinct shareholders' interests (Denis \& Osobov, 2008; Graham \& Kumar, 2006; Haesner \& Schanz, 2013). For example, in UK, pension funds have a great tax incentive to demand for dividends, being tax-exempt institutions, which makes the tax system very favorable to dividends in comparison to the tax treatment of capital gains (Bond, Chennells, \& Devereux, 1995). Firm size has also been proposed as an important determinant of dividend payout under the argument that larger firms are more stable and less inclined to depend on available cash flow for investment (DeAngelo, DeAngelo, \& Skinner, 2004).

Jensen (1986) called attention to the dividend distribution to shareholders as able to create agency conflicts. Since then, research has focused on this aspect of dividend policy. Under the agency conflicts theoretical framework, the use of dividend policy has also been pointed out as an additional mechanism for management monitoring given that high dividend payout reduces the free cash flow submitted to discretionary managerial control, this way functioning as an important instrument for management monitoring (Harada \& Nguyen, 2011; Jensen, 1986; López-Iturriaga \& Crisóstomo, 2010).

\subsection{DIVIDEND POLICY AND NONFINANCIAL FIRM AS THE CONTROLLING SHAREHOLDER}

The excess power of controlling shareholders has been the focus of attention of important body of literature on corporate governance given that relevant firm blockholders have incentives and ability to maintain internal control systems that fit their interests and ease the use of private benefits of 
control as predicted by the expropriation effect argument (Brandão \& Crisóstomo, 2015; Crisóstomo \& Brandão, 2016; Johnson, La Porta, Lopez-deSilanes, \& Shleifer, 2000; Shleifer \& Vishny, 1997). This excess power of controlling blockholders may also hold for the management monitoring hypothesis which is closely related to dividend policy.

Ownership concentration has been found as able to benefit management monitoring given that shareholders with greater power will be willing to bear the control costs, thus overcoming the free-rider problem, which is a strong characteristic of companies with low concentrated ownership in which shareholders with a low proportion of ownership have little interest in assuming monitoring costs for the benefit of all (Shleifer \& Vishny, 1986). This proposed effective action of high ownership concentration in monitoring management activity has been a topic of attention in the literature since long (Claessens \& Djankov, 1999; Demsetz \& Lehn, 1985).

The rationale on the management monitoring action and dividend policy is related to firm investment opportunities and the free cash flow available for managers. Under the Pecking Order proposal, a firm with good investment opportunities will try to maximize internal funds so that such a firm will tend to retain profit and restrict dividend payout and direct cash flow to finance investment (Myers, 1977; Myers \& Majluf, 1984). On the other hand, if the company does not have good growth opportunities, there would be no need, or justification, to retain profit and constrain the payment of dividends. In fact, in such a situation, higher dividend distribution may interesting for management monitoring given that it reduces the free cash flow available for the manager without good investment opportunities, restricting his discretionary power over free cash flow, thus limiting the eventual misuse of funds available, this way reducing the possibility that the manager incurs in moral risk (Jensen, 1986; La Porta et al., 2000).

There is an argument that suggests that the nature of relevant blockholders is able to affect firm investment and financing policies. The rationale is that better and more timely informed blockholders positively influence communication with external creditors. In this vein, certain blockholders may also be more effective in monitoring firm management, reducing the possibility of managerial misuse of internal funds (Goergen \& Renneboog, 2001). 
A number of works found evidence on the influence of controlling shareholders on firm investment and financial policies which may be related to dividend policy as abovementioned. Other firms in ownership structure appear as important players in this context signaling that such blockholders seem to be well and timely informed about firm investment opportunities and funding sources. In fact, there is evidence that the membership to corporate groups in Japan and India improves access to external credit market (Hoshi, Kashyap, \& Scharfstein, 1991; Lensink \& Van der Molen, 2010; Manos, Murinde, \& Green, 2007). Also in the context of investment policy, the presence of a nonfinancial firm as a relevant blockholder favors investment policy and reduces the intensity of financial constraints in USA (Allen \& Phillips, 2000). By being well and timely informed about firm growth opportunities and firm financial status, another firm as the controlling blockholder will be able to adequately decide on the best source of funds, internal or external, to maximize growth opportunities. This way, they will shape dividend policy that best fit their interests.

In the case of Brazil, the scenario shows a huge presence of a nonfinancial firm as the controlling stockholder (Crisóstomo, 2011) which signals a great interest on diversification and return maximization. In summary, the rationale is that a nonfinancial firm as the company's controlling shareholder will decide to use dividend policy for management monitoring by increasing dividend payout in the presence of free cash flow.

Hypothesis: Nonfinancial firm as the dominant controlling shareholder increases dividend payout given that dividend policy is used as a management control mechanism to reduce free cash flow available for managers.

\section{MODELS AND ECONOMETRIC METHOD}

Four dividend models are estimated to test the proposed hypothesis that another firm as the controlling shareholder leads to a positive effect of dividend payment: the Full Adjustment Model (Lintner, 1956), the Partial Adjustment Model (Lintner, 1956), the Waud Model (Waud, 1966), and the Earnings Trend Model (Fama \& Babiak, 1968). In accordance with the proposals of Short et al. (2002) these models are modified by the inclusion of an interactive dummy 
variable to account for the potential positive effect of a nonfinancial firm as the controlling shareholder, proxied by the presence of such a shareholder as the major one, on dividend policy as proposed under the monitoring hypothesis rationale.

\subsection{THE FULL ADJUSMENT MODEL (FAM)}

Model of Equation (1) stands for the Full Adjustment Model (FAM) that relates earnings (E) and dividends (D) for firm i at time t. Under the rationale of the Full Adjustment Model, if changes in income are permanent and a firm has a target payout ratio, then there is a positive link between changes in earnings ( $E i, t-E i, t-1)$ and changes in dividends ( $D i, t-D i, t-1)$ (Lintner, 1956). The proposal that a nonfinancial firm as the controlling shareholder may bias the payout ratio justifies the inclusion of a proxy for such a presence in the model, as done by Short et al. (2002). The hypothesis that firms with a nonfinancial firm as the controlling shareholder may follow a higher payout ratio may be tested by the inclusion of a cross variable that interacts changes in earnings ( $E i, t-E i, t-1)$ and a dummy variable (NFFCS) that is set to 1 if the firm-year observation has a nonfinancial firm as the major stockholder. This is the model in equation (1) that also controls for firm size (FSIZE).

$D_{i, t}-D_{i, t-1}=\beta_{0}+\beta_{1}\left(E_{i, t}-E_{i, t-1}\right)+\beta_{2}\left[\left(E_{i, t}-E_{i, t-1}\right) \cdot\right.$ NFFCS $]+\beta_{3}$ FSIZE $+\mu_{i, t}$

Coefficient $\beta_{1}$ is expected to be positive signaling that dividend changes follows earnings changes, $\beta_{2}$ is hypothesized to be positive suggesting that the presence of a nonfinancial firm as the controlling shareholder favors dividend payout with the purpose to reduce free cash flow available for managers.

In model of equation (1) and the three next ones, Dividend (D) is the annual firm dividend distributed to stockholders. The presence of a nonfinancial firm as the controlling shareholder is proxied by the dummy variable NFFCS that accounts for the presence of a nonfinancial firm that holds more than $50 \%$ of voting shares. The variable Earnings (E) corresponds to the annual firm profit. Firm size (FSIZE) is proxied by Ln of Total Assets. 


\subsection{THE PARTIAL ADJUSTMENT MODEL (PAM)}

Equation (2) corresponds to the Partial Adjustment Model (PAM) (Lintner, 1956). The Partial Adjustment Model suggests that the target level of dividend distribution (D) for firm $i$ at time $t$ is related to firm earnings (E). This way, changes in dividend payout $\left(D_{i, t}-D_{i, t-1}\right)$ will be directly affected by earnings and previous dividends.

The hypothesis that a nonfinancial firm as the controlling shareholder may induce higher dividend payout is tested with the use of a dummy variable that is set to 1 when there is such a blockholder. Then we construct a cross variable that interacts earnings for firm $\boldsymbol{i}$ at time $\boldsymbol{t}\left(\mathrm{E}_{\mathrm{i}, \mathrm{t}}\right)$ and the dummy variable (NFFCS) that indicates the presence of a nonfinancial firm that holds more that $50 \%$ of voting shares. This is the model in equation (2) that also controls for firm size (FSIZE). The partial adjustment process of the dividend change is considered by accounting for the effect of previous dividend payout ( $D_{i, t-1}$ and $D_{i, t-2}$ ) on dividend change.

$D_{i, t}-D_{i, t-1}=\beta_{0}+\beta_{1} E_{i, t}+\beta_{i, t}\left[E_{i, t} \cdot N F F C S\right]+\beta_{3} D_{i, t-1}+\beta_{4}$ FSIZE $+\mu_{i, t}$

\subsection{THE WAUD MODEL (WM)}

The Waud Model (WM) (Equation 3) uses aspects of both the full and partial adjustment models. The Waud Model proposes that the target dividend distribution, for firm $\boldsymbol{i}$ at time $\boldsymbol{t}$, is directly related to the long-run expected earnings. The actual dividend change follows a partial adjustment process, and the formation of expectation about earnings follows an adaptive expectation model (Short et al., 2002; Waud, 1966).

The proposal that a nonfinancial firm as the major shareholder leads to higher dividend payment is tested by the inclusion of a cross variable that interacts earnings (E) and the dummy variable that accounts for the presence of a nonfinancial firm as the dominant shareholder (NFFCS) so that the coefficient $\beta_{2}$ of the cross variable $\left(E_{i, t} \cdot N F F C S\right)$ is expected to be positive according the monitoring hypothesis.

$D_{i, t}-D_{i, t-1}=\beta_{0}+\beta_{1} E_{i, t}+\beta_{2}\left[E_{i, t} \cdot\right.$ NFFCS $]+\beta_{3} D_{i, t-1}+\beta_{4} D_{i, t-2}+\beta_{5}$ FSIZE $+\mu_{i, t}$ 


\subsection{THE EARNINGS TREND MODEL (ETM)}

The Earnings Trend Model (ETM) (Equation 4) is a modified version of the partial adjustment model. The ETM considers that there is a profit generating process for firm $\boldsymbol{i}$ at time $\boldsymbol{t}$, in a way that previous earnings affect present earnings (Fama \& Babiak, 1968; Short et al., 2002). The model also assumes that dividend payout target is dependent on expected earnings, following an adjustment process on which previous earnings and dividends are able to explain dividend change.

Assuming the explanatory power of ownership concentration on dividend policy, the profit generating process integrates a cross variable that interacts the dummy variable that accounts for the presence of a nonfinancial firm as the major stockholder (NFFCS) and previous earnings $\left(E_{i, t-1}\right)$. Under the monitoring hypothesis rationale the coefficient of $\left[\mathrm{E}_{\mathrm{i}, \mathrm{t}-1} \cdot \mathrm{NFFCS}\right]$ is expected to be positive. As the others, this model also controls for firm size.

$D_{i, t}-D_{i, t-1}=\beta_{0}+\beta_{1} E_{i, t}+\beta_{2} E_{i, t-1}+\beta_{3}\left[E_{i, t-1} \cdot N F F C S\right]+\beta_{4} D_{i, t-1}+\beta_{5}$ FSIZE $+\mu_{i, t}$

\section{METHOD AND SAMPLE}

\subsection{ECONOMETRIC METHOD}

Models are estimated using panel data methodology. This method allows the treatment of unobservable heterogeneity associated with fixed firm effects that can be eliminated from the equation through variable transformation by first differences (Arellano \& Bover, 1990). Coefficients are estimated using Arellano and Bond's (1998) system estimator that is more adequate when the period of study is relatively short and provides better estimators (Blundell \& Bond, 1998). Models are estimated using the two-step system estimator (SE) with adjusted standard errors for potential heteroskedasticity (Blundell \& Bond, 1998). This method takes into account the unobserved effect by transforming the variables into first differences and using the generalized method of moments (GMM) to deal with endogeneity problems. Endogeneity may occur for three factors (Wooldridge, 2002): (i) variable omission, that is related to unobserved variable due to difficulties in obtaining data; (ii) variable 
measurement errors, that is related to problems in data collection or imperfect instruments; (iii) simultaneity, that occurs when there is a mutual relation between the dependent and the explanatory variable.

Validity of model estimations has been checked through the Hansen test of over-identification of restrictions. This test examines the lack of correlation between the instruments and the error term. The use of first-difference transformations may lead to some degree of first-order serial correlation that does not invalidate the results. However, the presence of second-order serial correlation does signal omitted variables and this absence of second-order correlation in the residuals has been checked by the Arellano-Bond test of second order auto-correlation in the residuals.

Due to high variance, variables have been log transformed. The presence of negative values led to the application of a log transformation that takes that situation into account. This way, variables have been log transformed to natural logarithm following the methodology of Elnathan, Gavious and Hauser (2010):

$$
\begin{cases}\ln (x+1), & x \geq 0 \\ -\ln (-x+1), & x<0\end{cases}
$$

This log transformation is monotone and information-preserving. As can be seen, it ensures that $L(X)$ is defined when $X$ is zero (by the addtion of 1) and that negative values are not discarded.

\subsection{SAMPLE}

The sample used is an unbalanced panel data of 1.890 firm-year observations related to 234 companies in the period 1996-2012. This period allows the assessment of firm dividend policy in Brazil in a long period of time which makes results more consistent. Annual financial and ownership data of Brazilian firms have been collected from the Economática database. Table 1 allows one to see that sample firms are distributed among a diversity of 12 sectors of the economy in Brazil. Only firm-year observations with complete data about dividends, earnings, and ownership concentration have been kept 
in the sample. The late availability of ownership data resulted in a reduced number of observations in the initial years of study.

Table 1: Panel data of firms by industry

\begin{tabular}{lrrrrr}
\hline & \multicolumn{2}{c}{ Firm-year } & \multicolumn{2}{c}{ Firms } \\
& observations & & \\
\hline Industry & N & \% & N & \% \\
\hline Mining, steel and chemical products & 401 & 21.22 & 46 & 19.66 \\
Electric energy, gas supply, and water & 268 & 14.18 & 32 & 13.68 \\
Building e transportation & 258 & 13.65 & 33 & 14.10 \\
Business sector service & 248 & 13.12 & 37 & 15.81 \\
Food, drink e tobacco & 150 & 7.94 & 21 & 8.97 \\
Textile, clothing, leather and footwear & 143 & 7.57 & 18 & 7.69 \\
Trade and retailing & 107 & 5.66 & 10 & 4.27 \\
Machinery and equipment & 96 & 5.08 & 11 & 4.70 \\
Communication and media & 73 & 3.86 & 10 & 4.27 \\
Petroleum, gas and fuel products & 73 & 3.86 & 8 & 3.42 \\
Wood, paper and paper products & 65 & 3.44 & 6 & 2.56 \\
Other miscellaneous industries & 8 & 0.42 & 2 & 0.85 \\
\hline
\end{tabular}

\section{DISCUSSION AND RESULT ANALYSIS}

Chart 1 presents the movement of net profit and dividend payout throughout the period of study. There seems to be a joint movement of dividends and earnings as predicted in dividend studies since the early proposals about the determinants of dividend payout under the rationale that dividend payout requires benefit (Fama \& Babiak, 1968; Lintner, 1956; Waud, 1966). Theoretical proposals on dividend policy suggest that there is information content on dividend changes about future earnings. The proposition is that dividend increase transmits good news while dividend decrease is interpreted as bad news, and that the market is sensitive to such changes (Bhattacharya, 1979; John \& Williams, 1985; Miller \& Rock, 1985). Furthermore, it is also observed that firms indeed try to keep dividend payout policy, avoiding decrease as predicted in the literature (Black, 1976; X. He, Li, Shi, \& Twite, 2016; Z. He, Chen, Huang, Pan, \& Shi, 2016; Lintner, 1956). 
Chart 1: Evolution of net profit and dividends along the period of study

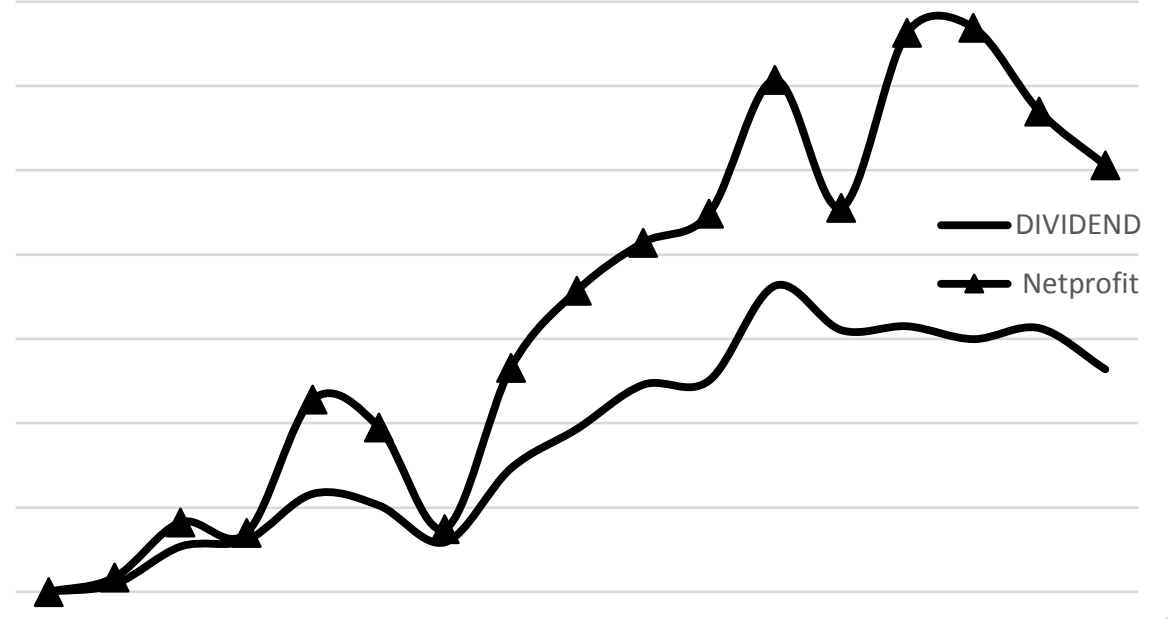

Note: Values of net profit and dividends (divided by 1 million).

Table 2 shows the numbers on the presence of a nonfinancial firm as the dominant shareholder in Brazil. In fact, there is a high proportion of firms on which there is another firm as the dominant stockholder, i.e., holding more than $50 \%$ of voting shares. Throughout the period of study, on average, $24,23 \%$ of Brazilian listed firms have a nonfinancial firm as the controlling blockholder. This situation highlights the relevant role played by a nonfinancial firm as the dominant controlling shareholder over firm policies in Brazil. 
Table 2: Presence of a nonfinancial firm as the controlling shareholder

\begin{tabular}{lrrrrr}
\hline & $\begin{array}{c}\text { Firm has another } \\
\text { nonfinancial firm as } \\
\text { the controlling } \\
\text { shareholder }\end{array}$ & $\begin{array}{c}\text { Firm does not have } \\
\text { another nonfinancial } \\
\text { firm as the } \\
\text { controlling }\end{array}$ & Total \\
shareholder & \\
\hline Year & $\mathrm{N}$ & $\%$ & $\mathrm{~N}$ & $\%$ & $\mathrm{~N}$ \\
\hline 1996 & 1 & $50.00 \%$ & 1 & $50.00 \%$ & 2 \\
1997 & 4 & $30.77 \%$ & 9 & $69.23 \%$ & 13 \\
1998 & 18 & $25.35 \%$ & 53 & $74.65 \%$ & 71 \\
1999 & 26 & $24.53 \%$ & 80 & $75.47 \%$ & 106 \\
2000 & 33 & $27.50 \%$ & 87 & $72.50 \%$ & 120 \\
2001 & 37 & $28.46 \%$ & 93 & $71.54 \%$ & 130 \\
2002 & 42 & $31.34 \%$ & 92 & $68,66 \%$ & 134 \\
2003 & 43 & $30,94 \%$ & 96 & $69,06 \%$ & 139 \\
2004 & 40 & $28,57 \%$ & 100 & $71,43 \%$ & 140 \\
2005 & 37 & $28,91 \%$ & 91 & $71,09 \%$ & 128 \\
2006 & 33 & $24.81 \%$ & 100 & $75.19 \%$ & 133 \\
2007 & 33 & $22.45 \%$ & 114 & $77.55 \%$ & 147 \\
2008 & 31 & $21.53 \%$ & 113 & $78.47 \%$ & 144 \\
2009 & 29 & $20.28 \%$ & 114 & $79.72 \%$ & 143 \\
2010 & 21 & $16.94 \%$ & 103 & $83.06 \%$ & 124 \\
2011 & 15 & $13.27 \%$ & 98 & $86.73 \%$ & 113 \\
2012 & 15 & $14.56 \%$ & 88 & $85.44 \%$ & 103 \\
\hline Total & 458 & $24.23 \%$ & 1432 & $75.77 \%$ & 1890 \\
\hline & & & & & \\
\hline
\end{tabular}

The proposal that the presence of a nonfinancial firm as the controlling shareholder influences dividend policy is contrasted by estimating the models presented in section 3: Full Adjustment Model (FAM), Partial Adjustment Model (PAM), Waud Model (Waud) and Earnings Trend Model (ETM). Such traditional dividend models were adjusted to include the presence of a nonfinancial firm as the controlling shareholder.

Results exhibited in Table 3 show that, in fact, changes in dividend policy are influenced by firm earnings $(E)$ and changes in earnings $\left(E_{i, t}-E_{i}, t-1\right)$ which is in accordance with the initial proposals about dividend payout (Fama \& Babiak, 1968; Lintner, 1956; Waud, 1966). Firm profit coefficient is positive and statistically significant related with dividend policy, confirming the theory that the payment of dividends is associated with firm profit. This is consistent in the four models estimated (FAM, PAM, Waud, ETM). Present earnings $\left(E_{i, t}\right)$ have a positive effect on dividend distribution as can be observed in models PAM, Waud and ETM. 
Looking at the effect of the presence of a nonfinancial firm as the major shareholder over dividend policy, it can be noticed that the presence of such controlling shareholder ( $E_{i, t}$ NFFCS) favors positive changes on dividend distribution ( $D I V$ - $\operatorname{DIV}_{i, t-1}$ ). This result confirms that the presence of $a$ nonfinancial firm as the major shareholder, i.e, with more than $50 \%$ of voting rights, is a factor than contributes to the increase of dividend distribution as hypothesized under the rationale of the monitoring hypothesis.

Table 3: Model estimates for the effect of the presence of a nonfinancial firm as the firm major shareholder over dividend distribution

\begin{tabular}{|c|c|c|c|c|}
\hline \multirow[b]{2}{*}{$\begin{array}{l}\text { Explanatory } \\
\text { variables }\end{array}$} & \multicolumn{4}{|c|}{ Model } \\
\hline & FAM & PAM & WM & ETM \\
\hline $\begin{array}{l}E_{t i}-E_{(t-1) i} \\
\left(E_{t i}-E_{(t-1) i}\right) \cdot N F F C S\end{array}$ & $\begin{array}{l}0,195 * * * \\
0,637 * * *\end{array}$ & & & \\
\hline $\begin{array}{l}E_{t i} \\
E_{(t-1) i}\end{array}$ & & $1,738^{* * *}$ & $0,163 * * *$ & $\begin{array}{l}0,918^{* * *} \\
-0,368^{*}\end{array}$ \\
\hline $\mathrm{E}_{\mathrm{ti}} \cdot \mathrm{NFFCS}$ & & $1,177 * *$ & $0,555 * * *$ & \\
\hline$E_{(t-1) i} \cdot N F F C S$ & & & & $0,805 * * *$ \\
\hline$D_{(t-1)}$ & & - & - & - \\
\hline$D_{(t-1) i}$ & & $4,664 * * *$ & $0,909 * * *$ & $1,462 * * *$ \\
\hline$D_{(t-2) i}$ & & & $0,190 * * *$ & \\
\hline FSIZE & $0,203 * *$ & $4,931 * *$ & $0,660 * * *$ & $0,792 *$ \\
\hline $\mathrm{N}$ & 1890 & 1890 & 1890 & 1890 \\
\hline $\mathrm{F}$ & $56,39 * * *$ & $32,80 * * *$ & $29,44 * * *$ & $7,22 * * *$ \\
\hline J de Hansen & 0,154 & 0,436 & 0,296 & 0,278 \\
\hline AR (2) & 0,106 & 0,928 & 0,112 & 0,114 \\
\hline
\end{tabular}

Note: FAM = Full Adjustment Model, PAM = Partial Adjustment Model, Waud $=$ Waud Model, ETM $=$ Earnings Trend Model. In all models, the dependent variable is the change on dividend distribution ( $D I V-D I V_{t-1}$ ). $E=$ firm earnings in year $t . D=$ firm dividend distribution in year t. NFFCS = dummy variable that is set to 1 when the firm i has a major shareholder (a shareholder with more $50 \%$ of voting shares) in year $t$. Hansen is the test of overidentifying restrictions. AR2 is the test of absence of secondorder correlation in the residuals. $* * *, * *, *$ correspond to statistical significance of the coefficients at 1,5 , and 10 percent levels, respectively.

As previously mentioned, validity of models were checked through the Hansen test of over-identification of restrictions. The Hansen test examines the lack of correlation between the instruments and the error term. The use of first-difference transformations may lead to some degree of first-order serial correlation, although this correlation does not invalidate the results. As shown 
in Table 3, the Hansen test does not reject the null hypothesis of valid instruments. Additionally, the presence of second-order serial correlation, which does signal omitted variables, was tested through the Arellano-Bond test of second order serial correlation (AR2). As can be seen in Table 3, the AR2 test did reject the null hypothesis that predicts the absence of second order auto-correlation in the residuals.

Overall, the findings that the presence of a nonfinancial firm as the dominant controlling shareholder increases dividend payout in the Brazilian market are robust for a set of distinct relevant dividend models. Model estimates have produced consistent results that give support for the hypothesis that there exists a positive relation between dividend payout and the presence of a nonfinancial firm as the dominant controlling shareholder of the Brazilian firm. In fact, such positive association is a strong indication that a nonfinancial firm as the dominant controlling shareholder, as proxied by the presence of a nonfinancial firm as the major shareholder, favors the use of dividend policy as an instrument for management monitoring.

\section{CONCLUDING REMARKS}

Dividend policy under the Agency conflicts theoretical framework seems to have been the main focus of attention of dividend policy research more recently, following the body of literature that has found results signaling the dependency of dividend payout on the earnings level and the trend of firms in maintaining dividend policy. In fact, there seems to be preferences for dividend policy from different stakeholders -shareholders or managers-. Ownership structure has been considered as able to matter for a number of firm policies, among them, the dividend policy.

The agency conflicts dealt under the Agency Theory have been studied and some hypotheses on the link between such conflicts and dividend policies have been proposed. Among them is the monitoring hypothesis that predicts the use of dividend policy for management monitoring purposes, given that dividend payout is closely related to the free cash flow available for managers. Less cash flow available for managers reduces the risk of moral harzard. The objective of this work was to analyze the effect of a nonfinancial firm as the controlling blockholder on the dividend policy of the Brazilian firm. A 
nonfinancial firm as the controlling shareholder is powerful enough to decide on firm policies based on its complete knowledge about the firm and its growth opportunities. Such a controlling shareholder may be interested in dividend payout for investment return. However, the higher payout may be even more related to the interest in reducing management discretionary power over free cash flow as proposed by the monitoring hypothesis.

The analysis of the results show that indeed a nonfinancial firm as the controlling blockholder of the Brazilian firm is directly related to higher levels of dividend distribution which is a strong signal that a nonfinancial firm uses dividend policy for management monitoring purposes. Besides, the results also show that firm earnings has an important role on dividend adjustments as traditionally proposed. As theoretically predicted, firm size is also positively related to dividend distribution.

The paper contributes to the debate on dividend policy by providing evidence from an important emerging market where such research still requires further development. The evidence provided that nonfinancial firm as the controlling shareholder matters for dividend policy in Brazil helps to better understand the role of ownership structure on firm policies. 


\section{REFERENCES}

Allen, J. W., \& Phillips, G. M. (2000). Corporate Equity Ownership, Strategic Alliances, and Product Market Relationships. Journal of Finance, 55(6), 2791-2815.

Arellano, M., \& Bond, S. (1998). Dynamic panel data estimation using DPD98 for Gauss: A guide for users Mimeo. London: The Institute for Fiscal Studies.

Arellano, M., \& Bover, O. (1990). La econometria de datos de panel. Investigaciones Económicas, 14(1), 3-45.

Barclay, M. J., \& Smith, C. W. J. (2005). The Capital Structure Puzzle: The Evidence Revisited. Journal of Applied Corporate Finance, 17(1), 8-17.

Bhattacharya, S. (1979). Imperfect Information, Dividend Policy, and "The Bird in the Hand" Fallacy. The Bell Journal of Economics, 10(1), 259-270.

Black, F. (1976). The dividend puzzle. Journal of Portfolio Management, 2, 58.

Blundell, R., \& Bond, S. R. (1998). Initial conditions and moment restrictions in dynamic panel data models. Jounal of Econometrics, 87, 115-143.

Bøhren, Ø., Josefsen, M. G., \& Steen, P. E. (2012). Stakeholder conflicts and dividend policy. Journal of Banking and Finance, 36(10), 2852-2864. doi: http://dx.doi.org/10.1016/j.jbankfin.2012.06.007

Bond, S., Chennells, L., \& Devereux, M. (1995). Company Dividends and Taxes in the UK. Fiscal Studies, 16(3), 1-18. doi: 10.1111/j.14755890.1995.tb00224.x

Brandão, I. F., \& Crisóstomo, V. L. (2015). Concentração de propriedade e qualidade da governança da empresa brasileira. Revista Brasileira de Finanças, 13(3), 438-469.

Claessens, S., \& Djankov, S. (1999). Ownership Concentration and Corporate Performance in the Czech Republic. Journal of Comparative Economics, 27(3), 498-513. doi: http://dx.doi.org/10.1006/jcec.1999.1598

Crisóstomo, V. L. (2011). Inversión, Restricción Financiera y Estructura de Propiedad en Brasil (1 ed.). Saarbrücken: Editorial Académica Española (LAP LAMBERT Academic Publishing GmbH \& Co. KG).

Crisóstomo, V. L., \& Brandão, J. W. (2016). Ownership Concentration Affects Dividend Policy of the Brazilian Firm. Revista de Finanças Aplicadas, 7(3), 1-22.

DeAngelo, H., DeAngelo, L., \& Skinner, D. J. (2004). Are dividends disappearing? Dividend concentration and the consolidation of earnings. 
Journal of Financial Economics, 72(3), 425-456. doi: 10.1016/S0304405X(03)00186-7

DeAngelo, H., DeAngelo, L., \& Skinner, D. J. (2008). Corporate Payout Policy. Foundations and Trends in Finance, 3(2-3), 95-287. doi: $10.1561 / 0500000020$

Demsetz, H., \& Lehn, K. (1985). The Structure of Corporate Ownership: Causes and Consequences. Journal of Political Economy, 93(6), 11551177.

Denis, D. J., \& Osobov, I. (2008). Why do firms pay dividends? International evidence on the determinants of dividend policy. Journal of Financial Economics, 89(1), 62-82.

Dyck, A., \& Zingales, L. (2004). Private Benefits of Control: An International Comparison. The Journal of Finance, 59(2), 537-600.

Elnathan, D., Gavious, I., \& Hauser, S. (2010). An analysis of private versus public firm valuations and the contribution of financial experts. The International Journal of Accounting, 45, 387-412. doi: 10.1016/j.intacc.2010.09.001

Faccio, M., Lang, L. H. P., \& Young, L. (2001). Dividends and expropriation. The American economic review, 91(1), 54-78.

Fama, E. F., \& Babiak, H. (1968). Dividend Policy: An Empirical Analysis. Journal of the American Statistical Association, 63(324), 1132-1161.

Florackis, C., Kanas, A., \& Kostakis, A. (2015). Dividend policy, managerial ownership and debt financing: A non-parametric perspective. European Journal of Operational Research, 241(3), 783-795. doi: 10.1016/j.ejor.2014.08.031

Goergen, M., \& Renneboog, L. (2001). Investment Policy, Internal Financing and Ownership Concentration in the UK. Journal of Corporate Finance, Volume 7, Issue 3, pp. 257-284, September/2001., 7(3), 28.

Gopalan, R., Nanda, V., \& Seru, A. (2014). Internal Capital Market and Dividend Policies: Evidence From Business Groups. Review Of Financial Studies, 27(4), 1102-1142. doi: 10.1093/rfs/hhu004

Gordon, M. J. (1959). Dividends, Earnings, and Stock Prices. The Review of Economics and Statistics, 41(2), 99-105.

Graham, J. R., \& Kumar, A. (2006). Do dividend clienteles exist? Evidence on dividend preferences of retail investors. The Journal of Finance, 61(3), 1305-1336. doi: 10.1111/j.1540-6261.2006.00873.x

Gugler, K., \& Yurtoglu, B. B. (2003). Corporate governance and dividend pay-out policy in Germany. European economic review, 47(4), 731-758. doi: 10.1016/S0014-2921(02)00291-X 
Guthrie, K., Sokolowsky, J., \& Wan, K.-M. (2012). CEO Compensation and Board Structure Revisited. The Journal of Finance, 67(3), 1149-1168. doi: 10.1111/j.1540-6261.2012.01744.x

Gutiérrez Urtiaga, M., \& Sáez Lacave, M. I. (2014). La política de dividendos de las empresas con accionistas de control. InDret - Revista para el Análisis del Derecho, 3, 1-27.

Haesner, C., \& Schanz, D. (2013). Payout Policy Tax Clienteles, Ex-dividend Day Stock Prices and Trading Behavior in Germany: The Case of the 2001 Tax Reform. Journal of Business Finance \& Accounting, 40(3-4), 527-563. doi: $10.1111 /$ jbfa. 12018

Harada, K., \& Nguyen, P. (2011). Ownership concentration and dividend policy in Japan. Managerial Finance, 37(4), 362-379. doi: 10.1108/03074351111115313

Harris, L. E., Hartzmark, S. M., \& Solomon, D. H. (2015). Juicing the dividend yield: Mutual funds and the demand for dividends. Journal of Financial Economics, 116(3), 433-451. doi: 10.1016/j.jfineco.2015.04.001

Harris, M., \& Raviv, A. (1991). The Theory of Capital Structure. Journal of Finance, 46(1), 297-355.

He, X., Li, M., Shi, J., \& Twite, G. (2016). Why do firms pay stock dividends: Is it just a stock split? Australian Journal of Management, 41(3), 508-537. doi: $10.1177 / 0312896214553858$

He, Z., Chen, X., Huang, W., Pan, R., \& Shi, J. (2016). External finance and dividend policy: a twist by financial constraints. Accounting \& Finance, 56(4), 935-959. doi: 10.1111/acfi.12245

Holanda, A. P., \& Coelho, A. C. D. (2014). Estrutura de Propriedade em Firmas Brasileiras: Trajetória entre 1998-2012. Revista de Finanças Aplicadas, 3, 1-39.

Hoshi, T., Kashyap, A., \& Scharfstein, D. (1991). Corporate structure, liquidity, and investment: evidence from Japanese industrial groups. Quarterly Journal of Economics, 106(1), 33-60.

Javakhadze, D., Ferris, S. P., \& Sen, N. (2014). An international analysis of dividend smoothing. Journal of Corporate Finance, 29, 200-220. doi: 10.1016/j.jcorpfin.2014.09.007

Jensen, M. C. (1986). Agency costs of free cash flow, corporate finance, and takeovers. The American Economic Review, 76(2), 323-329.

John, K., \& Williams, J. (1985). Dividends, Dilution, and Taxes: A Signalling Equilibrium. The Journal of Finance, 40(4), 1053-1070.

Johnson, S., La Porta, R., Lopez-de-Silanes, F., \& Shleifer, A. (2000). Tunneling. The American Economic Review, 90(2), 22-27. 
Khan, T. (2006). Company Dividends and Ownership Structure: Evidence from UK Panel Data. The Economic Journal, 116(510), C172-C189. doi: 10.1111/j.1468-0297.2006.01082.x

La Porta, R., López-de-Silanes, F., Shleifer, A., \& Vishny, R. W. (2000). Agency Problems and Dividend Policies around the World. The Journal of Finance, 55(1), 1-33. doi: 10.1111/0022-1082.00199

Leal, R. P. C., Carvalhal-da-Silva, A. L., \& Valadares, S. M. (2002). Estrutura de controle das companhias brasileiras de capital aberto. Revista de Administração Contemporânea, 6(1), 7-18. doi: 10.1590/S141565552002000100002

Lee, Y.-T., Liu, Y.-J., Roll, R., \& Subrahmanyam, A. (2006). Taxes and dividend clientele: Evidence from trading and ownership structure. Journal of Banking \& Finance, 30(1), 229-246. doi:

10.1016/j.jbankfin.2005.03.009

Lensink, R., \& Van der Molen, R. (2010). Does group affiliation increase firm value for diversified groups?: New evidence from Indian companies. Journal of Empirical Finance, 17(3), 332-344.

Lintner, J. (1956). Distribution of Incomes of Corporations Among Dividens, Retained Earnings, and Taxes. American Economic Review, 46, 97-113.

López-Iturriaga, F. J., \& Crisóstomo, V. L. (2010). Do leverage, dividend payout and ownership concentration influence firms' value creation? An analysis of Brazilian firms. Emerging Markets Finance and Trade, 46(3), 80-94. doi: 10.2753/REE1540-496X460306

Manos, R., Murinde, V., \& Green, C. J. (2007). Leverage and business groups: Evidence from Indian firms. Journal of Economics and Business, 59(5), 443-465.

Martins, A. I., \& Famá, R. (2012). O que revelam os estudos realizados no Brasil sobre política de dividendos? Revista de Administração de Empresas, 52(1), 24-39. doi: 10.1590_s0034-75902012000100003

Miller, M. H., \& Modigliani, F. (1961). Dividend Policy, Growth, and the Valuation of Shares. The journal of business, 34(4), 411-433.

Miller, M. H., \& Rock, K. (1985). Dividend Policy under Asymmetric Information. Journal of Finance, 40(4), 1031-1051.

Modigliani, F., \& Miller, M. H. (1958). The Cost of Capital, Corporation Finance and Theory of Investment. The American Economic Review, 48(3), 261-297.

Moreiras, L. M. F., Tambosi Filho, E., \& Garcia, F. G. (2012). Dividendos e informação assimétrica: análise do novo mercado. Revista de Administração da Universidade de São Paulo, 47(4), 671-682. doi: http://dx.doi.org/10.5700/rausp1066 
Mori, N., \& Ikeda, N. (2015). Majority support of shareholders, monitoring incentive, and dividend policy. Journal of Corporate Finance, 30, 1-10. doi: 10.1016/j.jcorpfin.2014.10.015

Myers, S. C. (1977). Determinants of Corporate Borrowing. Journal of Financial Economics, 5, 147-175.

Myers, S. C. (1984). The Capital Structure Puzzle. The Journal of Finance, 39(3), 575-592.

Myers, S. C., \& Majluf, N. S. (1984). Corporate Financing and Investment Decisions When Firms Have Information That Investors Do Not Have. Journal of Financial Economics, 13(2), 187-221.

Pindado, J., \& De la Torre, C. (2006). The Role of Investment, Financing and Dividend Decisions in Explaining Corporate Ownership Structure: Empirical Evidence from Spain. European Financial Management, 12(5), 661-687.

Procianoy, J. L., \& Verdi, R. S. (2009). Dividend clientele, new insights, and new questions: the Brazilian case. RAE-eletrônica, 8(1).

Renneboog, L., \& Trojanowski, G. (2007). Control structures and payout policy. Managerial Finance, 33(1), 43-64. doi: 10.1108/03074350710715809

Shleifer, A., \& Vishny, R. W. (1986). Large Shareholders and Corporate Control. Journal of Political Economy, 94(3), 461-488. doi: $10.1086 / 250042$

Shleifer, A., \& Vishny, R. W. (1997). A Survey of Corporate Governance. Journal of Finance, 52(2), 737-783.

Short, H., Zhang, H., \& Keasey, K. (2002). The link between dividend policy and institutional ownership. Journal of Corporate Finance, 8(2), 105-122. doi: http://dx.doi.org/10.1016/S0929-1199(01)00030-X

Stein, J. C. (2003). Agency, information, and corporate investment. In G. M. Constantinides, M. Harris \& R. M. Stulz (Eds.), Handbook of the Economics of Finance (pp. 111-165). Amsterdam: Elsevier, North-Holland.

Waud, R. (1966). Small Sample Bias due to Misspecification in the "Partial Adjustment" and "Adapted Expectations" Models. Journal of the American Statistical Association, 61(316), 134-145.

Wooldridge, J. M. (2002). Econometric analysis of cross section and panel data. Cambridge, MA: MIT Press. 